\title{
Development of a Highly Sensitive and Specific Assay to Detect Staphylococcus aureus in Bovine Mastitic Milk
}

\author{
H. U. Graber, ${ }^{* 1}$ M. G. Casey,† J. Naskova, ${ }^{*}$ A. Steiner, ${ }^{*}$ and W. Schaeren† \\ ${ }^{*}$ Clinic for Ruminants, Department of Clinical Veterinary Medicine, Vetsuisse-Faculty, University of Berne, Bremgartenstrasse 109a, \\ PO Box 8466, 3001 Berne, Switzerland \\ †Agroscope Liebefeld-Posieux Research Station ALP, Schwarzenburgstrasse 161, 3003 Berne, Switzerland
}

\begin{abstract}
Diagnosis of udder infections with Staphylococcus aureus by bacteriological milk testing of quarter milk samples is often not satisfactory. To get reliable results, repeated sampling is necessary, which is normally too expensive. Therefore, we developed a test that allows the highly specific detection of Staph. aureus in bovine milk samples at very low concentrations. It is based on a fast procedure to prepare bacteria from milk, followed by DNA extraction and quantitative PCR. The whole analysis is done within $5 \mathrm{~h}$. For clinical milk samples, the analytical sensitivity of the assay was 50.7 times and 507 times higher than conventional bacteriology with 100 and $10 \mu \mathrm{L}$, respectively. The diagnostic specificity was $100 \%$. The test is further characterized by a low intra- and interassay variability as well as by a good recovery of Staph. aureus from raw milk. Furthermore, a high correlation $(R=0.925)$ between the agar plate counts and the quantitative PCR methodology over the whole range of measurement was found. In addition, our test revealed considerably more positive results than bacteriology. Due to its favorable properties, the assay might become an important diagnostic tool in the context of bovine mastitis caused by Staph. aureus.
\end{abstract}

Key words: real-time quantitative polymerase chain reaction, mastitic, Staphylococcus aureus, milk

\section{INTRODUCTION}

Staphylococcus aureus is the most common cause of contagious mastitis in cattle (Schällibaum, 1999; Zecconi et al., 2005) and causes significant economic damage worldwide (IDF, 2005). Diagnosis of Staph. aureus by bacteriological testing of quarter milk samples is not satisfactory. Even under the best conditions $(100 \mu \mathrm{L}$ per sample tested), the average diagnostic sensitivity

Received December 29, 2006.

Accepted June 4, 2007.

${ }^{1}$ Corresponding author: hans.graber@knp.unibe.ch reaches only $75 \%$ for single sampling resulting in a false-negative recognition rate of $25 \%$ (Sears et al., 1990). In some cases, this sensitivity can be as low as $41 \%$ (Sears et al., 1990). Most routine diagnostic analyses, however, are done with smaller volumes (10 $\mu \mathrm{L}$; NMC, 1999; Zecconi et al., 2003), so the sensitivity is even lower. Diagnostic specificity varies between 92 and 96\% under routine conditions (Sears et al., 1991).

The microbiological detection of IMI by Staph. aureus is further impeded by the intermittent shedding of Staph. aureus in the milk and the intracellular survival of nonprofessional phagocytes (Almeida et al., 1996; Wesson et al., 1998). Therefore, a satisfying diagnostic sensitivity is only achieved if 3 consecutive samples are analyzed (Sears et al., 1990). Because triple sampling is too expensive in most cases, routine testing is accomplished with single sampling. From a clinical point of view, this limited diagnostic sensitivity is not sufficient because a negative bacteriological result does not necessarily mean that the corresponding quarter is actually free of a Staph. aureus infection. As a consequence, a considerable number of infected cows remain undetected and the control and eradication of Staph. aureus mastitis in a herd is therefore difficult.

To improve the diagnostics for Staph. aureus in mastitis, we developed a novel methodology including a fast and reliable preparation procedure for bacteria from bovine milk, DNA extraction, and specific detection by real-time quantitative PCR (QPCR). The described method showed a high analytical sensitivity and specificity as well as a high repeatability.

\section{MATERIALS AND METHODS}

The development and validation of the assay were done according to guidelines proposed by the OIE World Organisation for Animal Health (OIE, 2004), adapted for QPCR.

\section{Standard PCR}

The PCR was performed in $25 \mu \mathrm{L}$ containing $1 \times$ HotStarTaq Master Mix (Qiagen AG, Hombrechtikon, 
Table 1. Primers and probes used for real-time quantitative PCR, standard PCR, and nucleotide sequencing

\begin{tabular}{|c|c|c|c|}
\hline Gene (protein) & Primer/probe & Sequence $5^{\prime}-3^{\prime}$ & $\begin{array}{l}\text { Amplicon } \\
\text { size (bp) }\end{array}$ \\
\hline \multicolumn{4}{|c|}{ Real-time quantitative PCR } \\
\hline $\begin{array}{l}\text { nuc } \\
\text { (thermonuclease) }\end{array}$ & $\begin{array}{l}\text { QNuc-S } \\
\text { QNuc-AS }\end{array}$ & $\begin{array}{l}\text { CCTGAAGCAAGTGCATTTACGA }^{1} \\
\text { CTTTAGCCAAGCCTTGACGAACT }^{1} \\
\text { CATCAGCATAAATATACGCTAAGC }\end{array}$ & 166 \\
\hline & QNuc-P & CACGTCCA $^{1,3}$ & \\
\hline $\begin{array}{l}\mathrm{N} \text { gene (canine distemper } \\
\text { virus, neuraminidase) }\end{array}$ & $\begin{array}{l}\text { QCDVN-S } \\
\text { QCDVN-AS }\end{array}$ & $\begin{array}{l}\text { CATCAACTCTGTTTGCGGTCTTAC }^{1} \\
\text { CTTATTCTCCAACCAGCCTAATTGT }^{1} \\
\text { CTCATCTGCCTCAGAATCCAAACTT }^{1}\end{array}$ & 130 \\
\hline \multicolumn{2}{|c|}{ Standard PCR } & $\begin{array}{l}\text { GCTC } 1,3 \\
\text { rd PCR }\end{array}$ & \\
\hline clfA (clumping & & & \\
\hline factor A) & $\begin{array}{l}\text { clfA-1 } \\
\text { clfA-2 }\end{array}$ & $\begin{array}{l}\text { GGCTTCAGTGCTTGTAGG }^{2} \\
\text { TTTTCAGGGTCAATATAAGC }^{2}\end{array}$ & 975 \\
\hline coa (coagulase) & $\begin{array}{l}\text { coa-1 } \\
\text { coa-2 }\end{array}$ & $\begin{array}{l}\text { ATAGAGATGCTGGTACAGG } \\
\text { GCTTCCGATTGTTCGATGC }^{2}\end{array}$ & 640 \\
\hline $\begin{array}{l}\text { nuc } \\
\text { (thermonuclease) }\end{array}$ & Nuc-S & CTGGCATATGTATGGCAATTGTT ${ }^{1}$ & 664 \\
\hline $\mathrm{N}$ gene (canine distemper & Nuc-AS & $\begin{array}{l}\text { TATTGACCTGAATCAGCGTTGTCT } \\
\text { CGGAGGAGCAATCAGAGGGATAA }^{1}\end{array}$ & \\
\hline virus, neuraminidase) & CDVN-S CDVN-AS & GCAACCCAAGAGCCGGATACATAG $^{1}$ & 788 \\
\hline $\operatorname{spa}($ protein $\mathrm{A})$ & $\begin{array}{l}\text { spa-III } \\
\text { spa-IV }\end{array}$ & $\begin{array}{l}\text { CAAGCACCAAAAGAGGAA }{ }^{2} \\
\text { CACCAGGTTTAACGACAT }\end{array}$ & 268 \\
\hline nuc (thermonuclease) & $\begin{array}{l}\text { Nucleoti } \\
\text { NucSeq-S } \\
\text { NucSeq-AS }\end{array}$ & $\begin{array}{l}\text { sequencing } \\
\text { TGTATGGCAATTGTTTCAATATTAC } \\
\text { TT }^{1} \\
\text { TTTCGCTTGTGCTTCACTTTTTC }^{1}\end{array}$ & \\
\hline
\end{tabular}

Switzerland); $2.5 \mu \mathrm{L}$ of nucleic acid (NA); $300 \mathrm{n} M$ (final concentration) of each of the spa, coa, or clfA gene primers (Akineden et al., 2001); and $1 \mu M$ for both nuc gene primers, respectively (Table 1).All the primers were synthesized by Microsynth, Balgach, Switzerland. For the detection of each of the 4 genes, a prePCR step was run at $95^{\circ} \mathrm{C}$ for 15 min followed by 35 cycles under following conditions: denaturation at $94^{\circ} \mathrm{C}$ for $1 \mathrm{~min}$, annealing at $60^{\circ} \mathrm{C}\left(\mathrm{clfA} 57^{\circ} \mathrm{C}\right)$ for $1 \mathrm{~min}$, and extension at $72^{\circ} \mathrm{C}$ for $1 \mathrm{~min}$. The reaction was completed by a 10 min step at $72^{\circ} \mathrm{C}$ followed by cooling down to $4^{\circ} \mathrm{C}$. The PCR products were analyzed by agarose gel electrophoresis in $45 \mathrm{~m} M$ Tris-borate, $1 \mathrm{~m} M$ EDTA, $\mathrm{pH}=8.3$ (TBE) including GelRed stain (Biotium Inc., Hayward, CA). Gel staining was done by adding $6 \mu \mathrm{L}$ of the GelRed stock reagent to $60 \mathrm{~mL}$ of hot gel solution. The stained gels were viewed using a standard transilluminator $(312 \mathrm{~nm})$.

\section{DNA Sequencing of the Target Gene}

Based on database analyses and literature (Brakstad et al., 1992), we used the nuc gene as a target for the assay. This gene, coding for the thermonuclease, is highly specific for Staph. aureus and was not found in other staphylococcal species including Staphylococcus intermedius and Staphylococcus hyicus (Brakstad et al., 1992) or other mastitis-relevant bacteria. Unfortunately, all except one of the published sequences were from human Staph. aureus isolates and seemed to be different from the bovine strain. To verify this, the nuc gene of 20 epidemiologically unrelated Staph. aureus isolates from bovine mastitis milk was sequenced. The strains were provided by the Graeub Laboratory, Berne, Switzerland.

For each strain, single colonies grown on Columbia agar plates containing 5\% sheep blood (BA; BioMérieux Suisse s.a., Geneva, Switzerland) were incubated aerobically in $4 \mathrm{~mL}$ of trypticase soy broth (Becton, Dickinson and Company, Basel, Switzerland) at $37^{\circ} \mathrm{C}$ overnight. Then, NA containing DNA and RNA were extracted according to Chavagnat et al. (2002). In brief, $1 \mathrm{~mL}$ of culture was centrifuged at $18,000 \times \mathrm{g}$ for 10 $\min \left(20^{\circ} \mathrm{C}\right)$, the pellet was incubated in $50 \mathrm{mM} \mathrm{HCl}$ for $15 \mathrm{~min}$, followed by further centrifugation $(18,000 \times g$, $10 \mathrm{~min}$ ). The pelleted bacteria were washed in $1 \mathrm{~mL}$ of Tris-EDTA-sucrose buffer $(100 \mathrm{~m} M$ Tris/HCl, $10 \mathrm{~m} M$ EDTA, 25\% sucrose (wt/vol), $\mathrm{pH}=8.0)$, centrifuged at 
$18,000 \times g$ for $10 \mathrm{~min}$ and lysed in $1 \mathrm{~mL}$ Tris-EDTAsucrose buffer containing $2.5 \mathrm{mg}$ of lysozyme (Merck, Berne, Switzerland) and 100 U of mutanolysin (Sigma, Buchs, Switzerland) for $60 \mathrm{~min}$ at $37^{\circ} \mathrm{C}$. After a further centrifugation step $(18,000 \times g, 10 \mathrm{~min})$, NA was extracted using the High Pure PCR Template Preparation Kit (Roche Diagnostics, Rotkreuz, Switzerland). The eluates were checked for DNA integrity and quantity by agarose gel electrophoresis in TBE together with GelRed stain. Standard PCR for the nuc gene was done as described above. The resulting amplicon (664 bp) was purified using the QIAquick PCR Purification Kit (Qiagen).

The DNA concentration of the eluates was measured by spectroscopy using Nanodrop ND-1000 spectrophotometer (Nanodrop Technologies, Rockland, DE). One hundred nanograms was then added to a total volume of $10 \mu \mathrm{L}$ containing $20 \mathrm{pmol}$ of one of the nuc gene sequencing primers (Table 1). The sense primer started at nucleotide 31 (nucleotide 1: starting point of the coding sequence), the antisense primer ended at nucleotide 636 . The sequencing procedures were done by the sequencing facility of the Microsynth company. Each amplicon was sequenced on both strands.

\section{Extraction of Bacterial Nucleic Acids from Bacteria in Milk}

Milk $(400 \mu \mathrm{L})$ of each sample was pipetted to a solution containing $250 \mu \mathrm{L}$ of Triton X-100 2\% (wt/vol; Merck), $150 \mu \mathrm{L}$ of Lactobacillus casei $\left(1.5 \times 10^{9} \mathrm{cfu}\right)$, and $125 \mu \mathrm{L}$ of $1 \%$ trypsin solution. The $1 \%$ trypsin solution was always freshly prepared by dissolving 100 mg of Trypsin 250 (Becton Dickinson AG, Basel, Switzerland) in $10 \mathrm{~mL}$ of $100 \mathrm{~m} M$ Tris $/ \mathrm{HCl}, \mathrm{pH}=7.8$, followed by incubation at room temperature for $30 \mathrm{~min}$. Before use, the solution was sterilized using a filter with a pore size of $0.22 \mu \mathrm{m}$. Lactobacillus casei was added to prevent the attachment of Staph. aureus to fat globules or to displace staphylococci already stuck to the globule surface. After incubating at $55^{\circ} \mathrm{C}$ for 15 min, $925 \mu \mathrm{L}$ of $n$-pentane (Merck) was added to the suspension followed by vortexing the samples 3 times for $10 \mathrm{~s}$. Afterward, the specimens were centrifuged at $18,000 \times g$ for $10 \mathrm{~min}\left(25^{\circ} \mathrm{C}\right)$. The supernatant was discarded, and the cell wall of the pelleted bacteria was lysed according to Chavagnat et al. (2002) as described above with the following modification: after the $\mathrm{NaOH}$ treatment, centrifugation was performed at 20,800 $\times \mathrm{g}$ for $10 \mathrm{~min}\left(4^{\circ} \mathrm{C}\right)$. The NA was then extracted again with the High Pure PCR Template Preparation Kit (Roche Diagnostics). The eluates $(200 \mu \mathrm{L})$ were checked for DNA integrity and quantity by standard agarose gel electrophoresis as described. The extracts were stored at $-20^{\circ} \mathrm{C}$ until further use.

The $L$. casei suspension used for milk spiking was prepared from a single colony of $L$. casei strain 18121 grown on a de Man, Rogosa, and Sharpe (MRS) agar plate (Biolife S.r.l., Milano, Italy), inoculated in $3 \mathrm{~mL}$ of MRS medium (Biolife) and incubated aerobically at $30^{\circ} \mathrm{C}$ for $48 \mathrm{~h}$. Then, $100 \mu \mathrm{L}$ of the suspension was subcultured again in $100 \mathrm{~mL}$ of MRS medium at the same conditions. Quantification of $L$. casei was done spectroscopically using a wavelength of $650 \mathrm{~nm}$ and a standard curve obtained from 3 independent dilution experiments including plating on MRS agar plates, incubation at $30^{\circ} \mathrm{C}$ for $48 \mathrm{~h}$, and counting the grown colonies. The bacteria were stored in MRS medium $\left(10^{10}\right.$ $\mathrm{cfu} / \mathrm{mL})$ at $4^{\circ} \mathrm{C}$ for up to $3 \mathrm{wk}$.

\section{Generation of an Internal Control for QPCR}

A plasmid vector containing the full-length $\mathrm{N}$ gene of the canine distemper virus ( $C D V-N$ gene) was used as an internal control (obtained from A. Zurbriggen, Department of Clinical Veterinary Medicine, University of Berne, Switzerland). The insert was verified by sequencing the sense strand using the $\mathrm{T} 7$ primer (Microsynth). Afterwards, the plasmid served as a template for a standard PCR to produce enough spiking DNA. For that reason, $10 \mathrm{ng}$ of plasmid DNA was added to a final volume of $25 \mu \mathrm{L}$ containing $1 \times$ HotStarTaq Master Mix (Qiagen), and $300 \mathrm{n} M$ (final concentration) of the CDVN-S and CDVN-AS primer (Table 1). Amplification was performed by a pre-PCR step at $95^{\circ} \mathrm{C}$ for $15 \mathrm{~min}$ followed by 33 cycles under the following conditions: $94^{\circ} \mathrm{C}$ for $1 \mathrm{~min}, 63^{\circ} \mathrm{C}$ for $1 \mathrm{~min}$, and $72^{\circ} \mathrm{C}$ for $1 \mathrm{~min}$. The reaction was finished by a 10 -min step at $72^{\circ} \mathrm{C}$ followed by cooling down to $4^{\circ} \mathrm{C}$. The PCR product (664 bp) was analyzed by agarose gel electrophoresis in TBE including GelRed stain and was purified with the QIAquick PCR Purification Kit (Qiagen) according to the protocol of the manufacturer. Quantification of the eluate DNA was done with the Nanodrop spectrometer.

\section{Real-Time Quantitative PCR}

To quantify DNA specific for Staph. aureus, 2 primers and a probe for the nuc target gene were designed (Table 1), amplifying a 166-bp fragment. The probe was labeled at the $5^{\prime}$ end with 6-carboxyfluorescein (FAM) and at the $3^{\prime}$ end with 6-carboxytetramethylrhodamin (TAMRA; Microsynth). Each $25 \mu \mathrm{L}$ of QPCR mixture contained 1× TaqMan Universal PCR master mix (Applied Biosystems, Rotkreuz, Switzerland), $900 \mathrm{n} M$ sense and antisense primer, $300 \mathrm{n} M$ probe and $3.5 \mu \mathrm{L}$ of NA extracted from bacteria in milk. The QPCR conditions 
were $50^{\circ} \mathrm{C}$ for $2 \mathrm{~min}$ and $95^{\circ} \mathrm{C}$ for $10 \mathrm{~min}$ followed by 45 cycles of $95^{\circ} \mathrm{C}$ for $15 \mathrm{~s}$ and $60^{\circ}$ for $1 \mathrm{~min}$. Cycling was performed in the GeneAmp 5700 Sequence Detection System (Applied Biosystems).

To ensure that negative results were not due to nonspecific inhibition of the QPCR assay, a second QPCR with the same NA was run, containing the internal control DNA (CDV-N amplicon), and CDV-N specific primers/probe (amplified fragment: $130 \mathrm{bp}$ ). For that reason, each reaction $(25 \mu \mathrm{L})$ was given $1 \times$ TaqMan Universal PCR master mix (Applied Biosystems), 300 $\mathrm{n} M$ sense and antisense primer, $300 \mathrm{n} M$ FAM/TAMRA labeled probe (Table 1; Microsynth), 3.5 $\mu \mathrm{L}$ bacterial $\mathrm{NA}$, and $10^{5}$ copies of the CDV-N amplicon. Cycling was done as described for the nuc gene QPCR.

The QPCR for both genes were run in duplicate. Results were considered to be positive if both reactions were positive. If only one reaction showed a positive result or the difference of the $2 \mathrm{CT}$ values $(\mathbf{C T}=$ cycles to reach the threshold) were more than 1.5 cycles, the QPCR were repeated. A reaction was considered negative if $n u c$ gene amplification resulted in a value $<10$ molecules/reaction. For each assay, a standard was included (in duplicates). For the nuc gene, it ranged between 10 to $3.8 \times 10^{4}$ molecules/reaction, for the CDV$\mathrm{N}$ gene between $10^{2}$ to $10^{6}$ molecules/reaction. In the case of the nuc gene, 1 molecule was considered as 1 staphylococcal cell equivalent (SCE).

\section{Assay Controls}

Various controls were included to monitor the whole procedure. To evaluate the preparation of Staph. aureus from milk, 1 sample of Staph. aureus negative raw milk was always coprocessed together with 2 samples spiked with 5,000 and $10^{6} \mathrm{cfu}$ of Staph. aureus/mL of raw milk, respectively. If one of the spiked samples were not within the adequate range $( \pm 2.5$ times the expected, nontransformed value), all the milk samples of the affected series were prepared again. This was necessary in one case.

For each QPCR run, no template controls were included. If they resulted positive, the run was repeated. All negative nuc gene QPCR results required detection of CDV-N DNA. The CDV-N QPCR was also used to check for PCR inhibitors in the NA extracts. If the slope of the amplification curve ( $\log _{10}$-transformed fluorescence intensities) was obviously flatter or the CT value was more than 2 cycles larger than the mean, the NA were diluted 1:10 with $\mathrm{H}_{2} \mathrm{O}$ and reanalyzed by both the nuc and CDV-N gene QPCR. In case of doubt, the NA were diluted.

\section{Identification of Staphylococcal Isolates}

To evaluate the analytical specificity of the QPCR method, a total of 38 epidemiologically unrelated Staph. aureus and 36 isolates of CNS from mastitic milk were analyzed (obtained from the Graeub Laboratory, Berne, Switzerland). All the isolates were gram-positive, catalase-positive cocci. They were further identified by PCR (see above) for the presence of the spa (protein A), coa (coagulase), and clfA (clumping factor A) genes. In the case of Staph. aureus, the isolates had to be positive for all the 3 genes, whereas the CNS had to be negative. In none of the 2 groups, strains had to be excluded due to unclear PCR results. In addition, 6 CNS isolates were used with known identity: Staphylococcus chromogens, Staphylococcus haemolyticus, Staphylococcus warneri, Staphylococcus xylosus (all obtained from Institute of Veterinary Bacteriology, University of Berne, Switzerland), Staph. intermedius (DSM 20373), and Staph. hyicus (DSM 20459) (both obtained from DSMZ: Deutsche Sammlung von Mikroorganismen und Zellkulturen $\mathrm{GmbH}$, Braunschweig, Germany). The necessary NA were extracted as described above.

\section{Generation of Pure DNA}

The analytical specificity of the QPCR assay was tested using pure sample DNA. For that reason, the contaminating RNA from the NA extracts was removed by RNase treatment. In particular, $2 \mu \mathrm{L}$ of RNase DNase-free (Roche Diagnostics) were added to $50 \mu \mathrm{L}$ of eluate and incubated at $37^{\circ} \mathrm{C}$ for $45 \mathrm{~min}$. The DNA was then purified with the High Pure PCR Product Purification Kit (Roche Diagnostics) and was quantified by the Nanodrop spectrophotometer. The NA extracts and the pure DNA were stored at $-20^{\circ} \mathrm{C}$ until further use.

\section{Clinical Milk Samples}

A total of 77 individual quarter milk samples were analyzed. They were collected between November 2004 and October 2005 from 38 cows in 11 herds. The cows were forestripped, and the first 15 to $20 \mathrm{~mL}$ of milk from each quarter were tested for macroscopically visible changes. Afterwards, milk samples were taken for the determination of SCC. Finally, the teats were thoroughly cleaned with gauze pledges soaked with ethanol $70 \%$, and individual quarter milk samples were collected aseptically in sterile vials. The samples were then transported to the laboratory at $4^{\circ} \mathrm{C}$. The milk samples taken for SCC determination were stored at $4^{\circ} \mathrm{C}$ and analyzed with a Fossomatic 5000 (Foss, Hillerød, Denmark) within $24 \mathrm{~h}$ of collection. The samples 
for the bacteriological and QPCR tests were stored at $-20^{\circ} \mathrm{C}$ until analysis.

By visual inspection, the milk of all the tested quarters was normal or only minimally changed. Thirtythree showed an SCC of $\leq 100,000$ cells $/ \mathrm{mL}$, which is considered to be normal (Hamann, 2003). The respective geometric mean was 32,600 cells/mL. Forty-four samples showed pathological SCC values $\geq 100,000$ cells $/ \mathrm{mL}$ (geometric mean $=601,000$ cell $\mathrm{s} / \mathrm{mL}$ ).

\section{Bacteriological Analysis of Clinical Milk Samples}

The milk samples (total 77) were thawed at $37^{\circ} \mathrm{C}$ for $5 \mathrm{~min}$ and gently rotated several times to obtain a homogeneous suspension. Then, $100 \mu \mathrm{L}$ of milk was placed with an Eppendorf pipette onto a BA agar plate. In addition, $100 \mu \mathrm{L}$ was plated out onto Baird Parker agar (BP; bioMérieux), supplemented with rabbit plasma fibrinogen to test for coagulase activity.

The agar plates were incubated aerobically at $37^{\circ} \mathrm{C}$ and were analyzed after 24 and $48 \mathrm{~h}$ of incubation. Bacteria were identified according to the guidelines of the National Mastitis Council (NMC, 1999), which include morphology, biochemical properties, and detection of hemolysis. On BA plates, colonies were considered typical for Staph. aureus if they were large, grayish-white to yellow, catalase-positive, and showed $\beta$ or double hemolysis. On BP plates, large black to gray colonies surrounded by an unambiguous, opaque precipitation halo were accepted as Staph. aureus. After 24 and 48 h, colonies typical for Staph. aureus were counted on BP and BA plates. If the bacteria on the plates had grown too densely to be counted, we diluted an aliquot of the respective milk samples up to $1: 10,000$ in PBS and then plated out once again onto BA and BP plates $(10 \mu \mathrm{L})$.

\section{Statistical Analysis}

Data is expressed as nontransformed or as log-transformed values (logarithm to the basis 10). Linear least square regression analysis was performed, with the QPCR results $\left(\log _{10} \mathrm{SCE} / \mathrm{mL}\right.$ ) forming the dependent variable and the bacteriological results $\left(\log _{10} \mathrm{cfu} / \mathrm{mL}\right)$ the independent variable. Normal distribution of the residuals was demonstrated by quantile-quantile plot followed by the Lilliefors test. To analyze whether the QPCR method reveals a positive result more frequently than the bacteriological method, the McNemar test was applied. For this purpose, the exact $P$-value was calculated manually. For all the other statistical analyses, the Systat 10 software package (Systat Software Inc., Richmond, CA) was used. Probability values $<0.05$ were considered to be significant.

\section{RESULTS}

\section{Target Gene Analysis}

The nuc gene was chosen as a target for our QPCR assay because this gene was shown to be highly specific for Staph. aureus. All except one of the published sequences, however, were obtained from human Staph. aureus isolates and own multiple sequence alignments of the human and the bovine strains revealed a few dissimilarities for the latter one. Therefore, to get a sound basis for selecting primers, which allow consistent nuc gene amplification of bovine strains, this gene was sequenced in 20 Staph. aureus isolates obtained from bovine mastitic milk (GenBank accession numbers EF529589 to EF529608).

The similarities between our bovine and the published human strains were consistently very high, ranging between 4 (98.8\%) and 8 substitutions per 649 sequenced nucleotides (99.4\%). Interestingly, 19 of the 20 bovine isolates showed 5 nucleotide substitutions at nucleotide 51, 113, 129, 538, and 633 that occurred exclusively in the bovine strains (position related to the MSSA476 strain of Staph. aureus). At position 51, the substitution resulted in an exchange of amino acid Ile vs. Met, at position 113 Phe vs. Tyr and at position 538 Glu vs. Lys. At the 2 remaining sites, the nucleotide changes were silent. The mutations were present in 2 alternative patterns of combination, and each of the 19 isolates could be attributed to one of the 2 patterns. The 20th isolate, however, was very closely related to the human N315 strain with only 2 mutations observed in the 648 nucleotides analyzed.

Based on these results, we designed 2 primers and a fluorescent probe for QPCR, which were expected to detect the nuc gene in all the bovine and human Staph. aureus isolates (Table 1 ).

\section{QPCR Assay Performance}

Using serial dilutions of a purified nuc gene amplicon, the assay was shown to give linear results between 10 and $10^{7} \mathrm{SCE} /$ assay. It was even possible to measure as low as 6 SCE/assay, but it was difficult to reproduce the results consistently. As a QPCR standard, therefore, we choose concentrations between 10 and $1.0 \times 10^{5} \mathrm{SCE}$ per reaction. For this range, the coefficient of correlation was 0.999 (see Figure 1). Moreover, the lowest value (10 SCE/assay) could always be well reproduced. The amplification efficiency was 0.96 (measured on the gradient).

\section{Analytical Specificity}

To determine the analytical specificity we used RNAfree DNA from the 38 Staph. aureus and the 36 CNS 


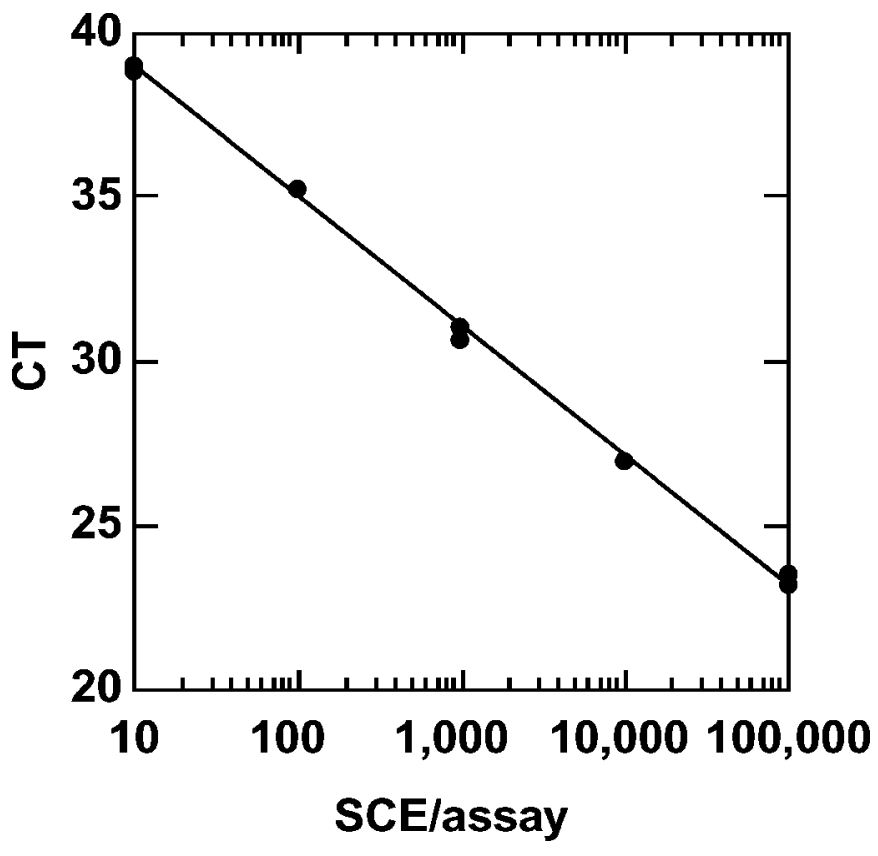

Figure 1. Standard curve obtained for real-time quantitative PCR (QPCR) using the nuc gene as the target. Serial dilutions of a purified nuc gene amplicon were made starting at $1.0 \times 10^{5}$ staphylococcal cell equivalent (SCE)/assay and ending at 10 SCE/assay. The dilutions were amplified by the standard $n u c$ gene QPCR protocol and the corresponding cycles to reach a defined threshold (CT) were determined. The SCE/assay values ( $\log _{10}$ scale) were then plotted against the obtained CT values. The observed coefficient of correlation was $R=-0.999$.

samples at concentrations of 5,000 and $100 \mathrm{SCE} /$ assay. Per assay we also added $L$. casei NA from $1.5 \times 10^{9}$ bacteria, imitating the standard QPCR conditions. Both the 100 as well as the 5,000 SCE/assay yielded positive results for all Staph. aureus strains. All CNS isolates, however, gave negative results.

A possible negative influence of CNS DNA on the amplification of the nuc gene was investigated by analyzing Staph. aureus DNA samples (250 SCE/assay) with a mixture of DNA extracts from 6 different CNS (Staph. chromogenes, Staph. haemolyticus, Staph. hyicus, Staph. intermedius, Staph. warneri, Staph. xylosus) at concentrations of $2.5 \times 10^{2}, 1.1 \times 10^{3}, 5.0 \times 10^{3}$, $5 \times 10^{4}$, and $5.0 \times 10^{5} \mathrm{SCE} /$ assay. No shift of the $n u c$ amplification signals was observed for any of the 6 amounts of CNS DNA compared with those of the nonspiked samples. The maximum difference between the highest and the lowest CT value was 0.6 cycles.

\section{Analytical Sensitivity}

The sensitivity of the assay procedure was evaluated by serial 1:10 dilutions of liquid, log-phase cultures of Staph. aureus in raw milk. These spiking experiments

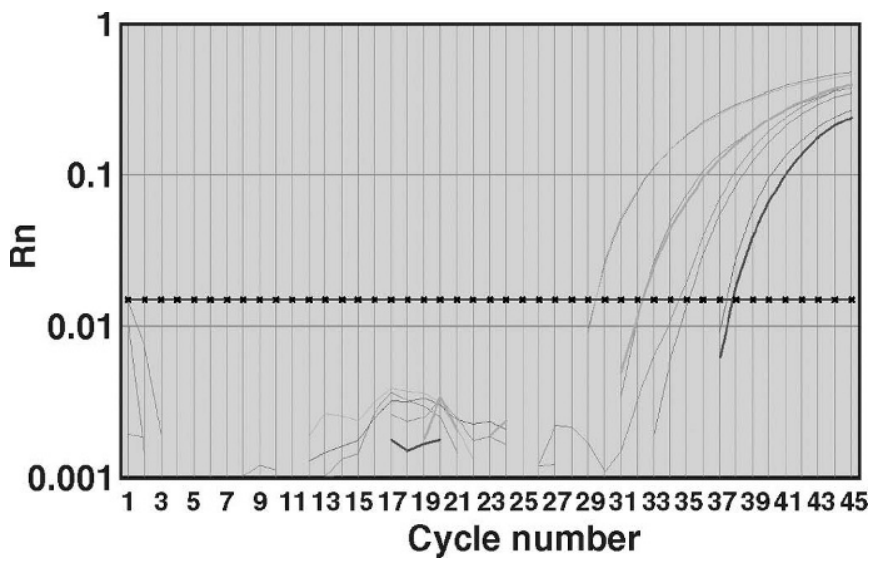

Figure 2. Representative amplification plot of real-time quantitative PCR (QPCR). Milk samples were spiked with Staphylococcus aureus containing $1.15 \times 10^{6}, 1.15 \times 10^{5} 1.15 \times 10^{4}$, and $1.15 \times 10^{3}$ $\mathrm{cfu} / \mathrm{mL}$ of milk, respectively. The samples were then processed in duplicates by the standard protocol for bacteria preparation, nucleic acids extraction and QPCR for the Staph. aureus-specific nuc gene. For all the concentrations, the plot shows an initial log-linear amplification. Furthermore, the cycle number increases consistently with decreasing Staph. aureus concentrations. Reproducible and consistent amplification below $1.15 \times 10^{3} \mathrm{cfu} / \mathrm{mL}$ was no longer possible. $\mathrm{Rn}=$ fluorescence intensity, arbitrary units ( $\log _{10}$-scale).

showed an analytical sensitivity as low as $460 \mathrm{cfu}$ of Staph. aureus per assay, which translates to $1.15 \times 10^{3}$ $\mathrm{cfu} / \mathrm{mL}$ milk (Figure 2: amplification curve with highest cycle number to reach the threshold). Figure 2 also demonstrates that the results produced by the assay (bacteria preparation, NA extraction, and QPCR) were consistent for a range between $1.15 \times 10^{3} \mathrm{cfu} / \mathrm{mL}$ and $1.15 \times 10^{6} \mathrm{cfu} / \mathrm{mL}$ of milk.

\section{Repeatability}

The intraassay variability was determined by repeated analyses of 2 samples spiked with $10^{6} \mathrm{cfu} / \mathrm{mL}$ of milk and $5 \times 10^{3} \mathrm{cfu}$ Staph. aureus per mL of milk. The samples were completely (bacteria preparation, NA extraction, QPCR) analyzed 10 times. The coefficient of variation (CV) was $1.1 \%$ for the higher and $3.2 \%$ for the lower content $\left(\log _{10}\right.$-transformed values). The interassay variability was calculated from the results using complete analysis of spiked milk samples on 7 different days. The CV was 3.7 and $6.5 \%$ for the samples containing $10^{6} \mathrm{cfu} / \mathrm{mL}$ and $5 \times 10^{3} \mathrm{cfu} / \mathrm{mL}$, respectively.

\section{Recovery}

Milk samples spiked with Staph. aureus from an overnight liquid culture in tryptic soy broth were used to determine the recovery. Eight replicates of milk samples spiked with aliquots of a 1:5,000 (experiment 1 ) or 
a 1:50,000 dilution (experiment 2) were subjected to standard bacterial preparation using $L$. casei and npentane. At the same time, 3 replicates of the corresponding stock cultures were coprocessed as described for liquid cultures. The following NA extraction of the resulting bacterial pellets (spiked milk samples and stock samples) as well as the QPCRs for the $n u c$ and the CDV-N genes were done according to our standard protocols.

For the stock cultures we obtained a geometric mean of $3.73 \times 10^{9} \mathrm{SCE} / \mathrm{mL}$ (experiment 1) and $4.53 \times 10^{9}$ $\mathrm{SCE} / \mathrm{mL}$ (experiment 2). The theoretical Staph. aureus concentrations of the spiked milks were $7.32 \times 10^{5} \mathrm{SCE} /$ $\mathrm{mL}$ (experiment 1) and $8.89 \times 10^{5} \mathrm{SCE} / \mathrm{mL}$ (experiment 2 ), respectively. The geometric means of the measured values were $6.86 \times 10^{5} \mathrm{SCE} / \mathrm{mL}$ (experiment 1 ) and 6.16 $\times 10^{4} \mathrm{SCE} / \mathrm{mL}$ (experiment 2). Based on these analyses, the recovery for experiment 1 was $93.9 \%\left(6.86 \times 10^{5}\right.$ / $7.32 \times 10^{5} \times 100$ ); for experiment 2 , a recovery of $69.3 \%$ was obtained.

\section{Relationship between Staphylococcal Cell Equivalents and Colony Forming Units}

To compare the SCE and cfu values, data that resulted from the 2 experiments were used to estimate the intraassay variability (see above). For the milk samples spiked with $10^{6} \mathrm{cfu}$ Staph. aureus per $\mathrm{mL}$, a geometric mean of $5.82 \times 10^{6} \mathrm{SCE} / \mathrm{mL}$ resulted. For $5 \times 10^{3} \mathrm{cfu} /$ $\mathrm{mL}$, the geometric mean was $2.82 \times 10^{3} \mathrm{SCE} / \mathrm{mL}$. If the SCE values were corrected for the recoveries and related to the corresponding cfu values, the following results were obtained: $6.2 \mathrm{SCE} / \mathrm{cfu}\left[5.82 \times 10^{6} /(0.939\right.$ $\left.\left.\times 10^{6}\right)\right]$ and $8.1 \mathrm{SCE} / \mathrm{cfu}$, respectively.

\section{Clinical Samples}

Of the 77 milk samples tested, 18 showed no growth, 35 contained Staph. aureus and 24 bacteria other than Staph. aureus. Pure cultures of Staph. aureus were found in 24 samples, whereas 11 contained a combination of Staph. aureus, CNS, Streptococcus spp., or Corynebacterium spp. Eighteen samples contained CNS, in part combined with Streptococcus spp., Corynebacterium spp., or both; 2 samples yielded pure cultures of Streptococcus spp. and Corynebacterium spp., respectively. Environmental contaminants were found in 4 samples.

Comparison between the agar plate and the QPCR method revealed 35 samples that tested bacteriologically positive for Staph. aureus. With QPCR, there were 46 positive samples. A QPCR result was never negative when the bacteriological had been positive. Statistical analysis with the McNemar test demonstrated that pos-

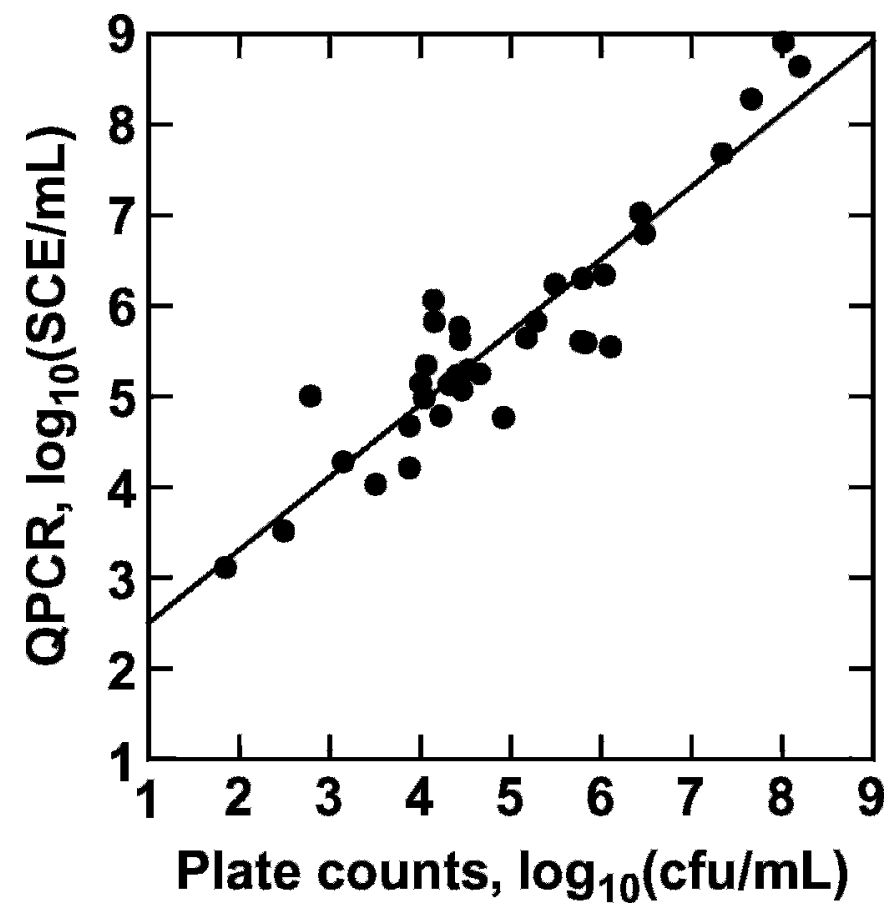

Figure 3. Quantification of Staphylococcus aureus in bovine clinical milk samples with the bacteriological plate count and the novel, real-time quantitative PCR-based method. Linear regression analysis with the combined data $\left(\log _{10}\right.$ transformed) resulted in a regression coefficient of $0.802(P<0.001)$, in a constant of $1.705(P<0.001)$ and in a Pearson's correlation coefficient $R$ of $0.925(P<0.001)$. SCE $=$ staphylococcal cell equivalents.

itive results with QPCR were more frequent than with bacteriology $(P<0.001)$.

In those 35 samples being positively tested by bacteriology, the plate counts were correlated with QPCR data (see Figure 3). A linear association was found over the whole range of measurement $\left(7.0 \times 10^{1}\right.$ to $1.55 \times 10^{8}$ $\mathrm{cfu} / \mathrm{mL})$. The correlation coefficient was $0.925(P<$ $0.001)$, the gradient $0.802(P<0.001)$, and the constant $1.705(P<0.001)$. Back transformation of the constant resulted in a value of $50.7\left(10^{1.705}\right)$.

Because we plated out $100 \mu \mathrm{L}$ of milk, the theoretical analytical sensitivity of bacteriology was $10 \mathrm{cfu} / \mathrm{mL}$. Considering the QPCR assay and expressed in cfu, its calculated diagnostic sensitivity in clinical milk samples was $0.197 \mathrm{cfu} / \mathrm{mL}$ (10 cfu/mL divided by 50.7$)$. As under routine conditions an aliquot of $10 \mu \mathrm{L}$ of milk is normally plated out, the assay was 507 times more sensitive $(0.0197 \mathrm{cfu} / \mathrm{mL})$ than routine bacteriology.

\section{DISCUSSION}

In this study we present a highly sensitive, specific and quantitative PCR test for the detection of Staph. aureus in bovine raw milk. The assay is based on a 
fast bacteria preparation procedure, followed by NA extraction and QPCR using the Staph. aureus specific nuc gene as target. The QPCR method we applied uses a $5^{\prime}$ nuclease, fluorogenic assay combined with realtime detection of PCR amplification products (TaqMan assay) as initially described by Heid et al. (1996). The QPCR was preferred because its sensitivity is greater than standard single-round PCR (Lanciotti et al., 2000) and is at least as sensitive as nested PCR (Locatelli et al., 2000). The latter PCR methodology was ruled out because it is known to be complicated, time-consuming, and prone to mistakes. In addition, it is not quantitative.

The QPCR method is characterized by a very high analytical sensitivity: for clinical milk samples, the new method was 50.7 and 507 times more sensitive than classical bacteriology using $100-$ and $10-\mu \mathrm{L}$ aliquots, respectively. In addition, the procedure showed a small intraassay and interassay variability with high and low Staph. aureus content. Furthermore, the recovery for both contents was high. Our data, however, indicate that recovery is slightly lower for small numbers of Staph. aureus than for high numbers. Nevertheless, our preparation procedure enabled us to recover Staph. aureus bacteria in raw milk samples at a high percentage.

With a coefficient of 0.925 the correlation between the numbers of Staph. aureus in milk quantified with the plate count method or the QPCR method was very high. This result is in opposition to that of Hein et al. (2005), who obtained a coefficient of correlation of only 0.74 . This marked difference can be mainly explained by the modified bacteria preparation procedure because the values of the QPCR itself, as far as they were published by the authors, are similar. In particular, spiking with $L$. casei turned out to be important because these bacteria are supposed to prevent the attachment of Staph. aureus to fat globules or to displace staphylococci already stuck to the globule surface. The effect was further enhanced by the n-pentane treatment. In addition, our preparation procedure is clearly faster than the procedure described by Hein et al. (2005) because the bacteria are prepared already after 25 min instead of $195 \mathrm{~min}$.

The obtained results, whereby bacteriology was less sensitive than the QPCR methodology, could lead to the interpretation, that the bacteria died off during the freezing and thawing process and therefore could not grow any more on the agar plates. Various authors (Schukken et al., 1989; Murdough et al., 1996) showed, however, that the freezing and storage at $-20^{\circ} \mathrm{C}$ does not affect the viability of Staph. aureus bacteria. On the contrary, the recovery of Staph. aureus in frozen milk samples may be even better than in fresh milk
(Villanueva et al., 1991; Godden et al., 2002). Therefore, on the basis of our trials with clinical milk samples we conclude that the nongrowing bacteria actually constitute the majority of the germs present, despite the optimal transportation and storage conditions. Relative to mastitis, we believe it to be without significance as to whether the bacteria are alive or dead. Because the nongrowing pathogens originated from the udder, they were at the time of the sampling in an environment that should have been free of such bacteria. Before dying, these agents had had the possibility to cause or maintain mastitis.

The usefulness of our method is its very high analytical specificity and sensitivity in clinical milk samples, which permits a reliable identification of Staph. aureus even then when most of the bacteria are dead or damaged and therefore no longer detectable on agar plates. In addition, definitive, quantitative results are available within $1 \mathrm{~d}$, in contrast to the classical bacteriological method, which requires $2 \mathrm{~d}$ of incubation. Furthermore, even untypical (e.g., purely alpha hemolytic) strains of Staph. aureus are correctly identified, unlike the DNase and coagulase reactions, which may lead to false negative or false positive results (Fantelli and Stephan, 2003). Moreover, the analyses on the diagnostic specificity of the QPCR method demonstrated that identification and quantification of Staph. aureus by QPCR is correct even when the milk sample contains high numbers of CNS, which are coprocessed during Staph. aureus preparation and DNA extraction. A definite identification is, however, of great clinical relevance, because mastitis caused by Staph. aureus or CNS differs clearly in its epidemiology and prognosis. The probability of successful treatment of Staph. aureus lies at only 40\% (Owens et al., 1997), whereas mastitis due to CNS benefits from a more favorable prognosis (Harmon et al., 1986). In addition, the 2 groups of pathogens differ in their resistance to antibiotics (Roesch et al., 2006). Finally, Staph. aureus is considered to be highly contagious, whereas CNS is less transmittable and less virulent and pathogenic (NMC, 1999).

The QPCR permits quantitative results within a large dynamic range. This characteristic simplifies the quantification substantially. Dilution steps, necessary for most bacteriological methods, can largely be omitted. A dilution of the extracted NA in our system is only required if competitive or enzymatic inhibitors are present. Such inhibitors are easily detected by the internal control, so that even in the absence of the amplification of the target gene definitive statements are allowed.

In conclusion, we developed a very sensitive, highly specific, and quantitative test that allows the detection of Staph. aureus in mastitic milk samples. It is based 
on a fast and effective preparation method for bacteria from milk, followed by conventional NA extraction and QPCR.

\section{ACKNOWLEDGMENTS}

This study was supported by grants of the Department of Clinical Veterinary Medicine, Vetsuisse-Faculty, University of Berne, Switzerland.

\section{REFERENCES}

Akineden, O., C. Annemüller, A. A. Hassan, C. Lämmler, W. Wolter, and M. Zschöck. 2001. Toxin genes and other characteristics of Staphylococcus aureus isolates from milk of cows with mastitis. Clin. Diagn. Lab. Immunol. 8:959-964.

Almeida, R. A., K. R. Matthews, E. Cifrian, A. J. Guidry, and S. P. Oliver. 1996. Staphylococcus aureus invasion of bovine mammary epithelial cells. J. Dairy Sci. 79:1021-1026.

Brakstad, O. G., K. Aasbakk, and J. A. Maeland. 1992. Detection of Staphylococcus aureus by polymerase chain reaction amplification of the nuc gene. J. Clin. Microbiol. 30:1654-1660.

Chavagnat, F., M. Haueter, J. Jimeno, and M. G. Casey. 2002. Comparison of partial tuf gene sequences for the identification of lactobacilli. FEMS Microbiol. Lett. 217:177-183.

Fantelli, K., and R. Stephan. 2003. Validation of DNAse reaction for identification of Staphylococcus aureus strains in routine mastitis diagnosis. Schweiz. Arch. Tierheilkd. 145:76-79.

Godden, S. M., J. T. Jansen, K. E. Leslie, N. L. Smart, and D. F. Kelton. 2002. The effect of sampling time and sample handling on the detection of Staphylococcus aureus in milk from quarters with subclinical mastitis. Can. Vet. J. 43:38-42.

Hamann, J. 2003. Definition of the physiological cell count threshold based on changes in milk composition. IDF Mastitis Newsl. 25:9-12.

Harmon, R. J., W. L. Crist, R. W. Hemken, and B. E. Langlois. 1986. Prevalence of minor udder pathogens after intramammary dry treatment. J. Dairy Sci. 69:843-849.

Heid, C. A., J. Stevens, K. J. Livak, and P. M. Williams. 1996. Real time quantitative PCR. Genome Res. 6:986-994.

Hein, I., H. J. Jorgensen, S. Loncarevic, and M. Wagner. 2005. Quantification of Staphylococcus aureus in unpasteurised bovine and caprine milk by real-time PCR. Res. Microbiol. 156:554-563.

IDF. 2005. Economic consequences of mastitis. Bulletin of the International Dairy Federation 394

Lanciotti, R. S., A. J. Kerst, R. S. Nasci, M. S. Godsey, C. J. Mitchell, H. M. Savage, N. Komar, N. A. Panella, B. C. Allen, K. E. Volpe,
B. S. Davis, and J. T. Roehrig. 2000. Rapid detection of West Nile Virus from human clinical specimens, field-collected mosquitoes, and avian samples by a TaqMan reverse transcriptase-PCR assay. J. Clin. Microbiol. 38:4066-4071.

Locatelli, G., F. Santoro, F. Veglia, A. Gobbi, P. Lusso, and M. Malnati. 2000. Real-time quantitative PCR for human Herpesvirus 6 DNA J. Clin. Microbiol. 38:4042-4048.

Murdough, P. A., K. E. Deitz, and J. W. Pankey. 1996. Effects of freezing on the viability of nine pathogens from quarters with subclinical mastitis. J. Dairy Sci. 79:334-336.

National Mastitis Council (NMC). 1999. Laboratory Handbook on Bovine Mastitis. Rev. ed. Nat. Mastitis Counc. Inc., Madison, WI.

OIE. Manual of diagnostic tests and vaccines for terrestrial animals, 5th edition. 2004. OIE World Organisation for Animal Health, Paris, France.

Owens, W. E., C. H. Ray, J. L. Watts, and R. J. Yancey. 1997. Comparison of success of antibiotic therapy during lactation and results of antimicrobial susceptibility tests for bovine mastitis. J. Dairy Sci. 80:313-317.

Roesch, M., V. Perreten, M. G. Doherr, W. Schaeren, M. Schällibaum, and J. W. Blum. 2006. Comparison of antibiotic resistance of udder pathogens in dairy cows kept on organic and on conventional farms. J. Dairy Sci. 89:989-997.

Schällibaum, M. 1999. Mastitis pathogens isolated in Switzerland, 1987-1996. IDF Mastitis Newsletter 23:14.

Schukken, Y. H., F. J. Grommers, J. A. Smit, D. Vandegeer, and A. Brand. 1989. Effect of freezing on bacteriologic culturing of mastitis milk samples. J. Dairy Sci. 72:1900-1906.

Sears, P. M., B. S. Smith, P. B. English, P. S. Herer, and R. N. Gonzalez. 1990. Shedding pattern of Staphylococcus aureus from bovine intramammary infections. J. Dairy Sci. 73:2785-2789.

Sears, P. M., D. J. Wilson, R. N. Gonzalez, and D. D. Hancock. 1991. Microbiological results from milk samples obtained premilking and postmilking for the diagnosis of bovine intramammary infections. J. Dairy Sci. 74:4183-4188.

Villanueva, M. R., J. W. Tyler, and M. C. Thurmond. 1991. Recovery of Streptococcus agalactiae and Staphylococcus aureus from fresh and frozen bovine milk. J. Am. Vet. Med. Assoc. 198:1398-1400.

Wesson, C. A., L. E. Liou, K. M. Todd, G. A. Bohach, W. R. Trumble, and K. W. Bayles. 1998. Staphylococcus aureus Agr and Sar global regulators influence internalization and induction of apoptosis. Infect. Immun. 66:5238-5243.

Zecconi, A., E. Binda, V. Borromeo, and R. Piccinini. 2005. Relationship between some Staphylococcus aureus pathogenic factors and growth rates and somatic cell counts. J. Dairy Res. 72:203-208.

Zecconi, A., R. Piccinini, and L. K. Fox. 2003. Epidemiologic study of intramammary infections with Staphylococcus aureus during a control program in nine commercial dairy herds. J. Am. Vet. Med. Assoc. 223:684-688. 